\title{
THE RELATION OF DIETARY PROTEIN CONSUMPTION TO N-15 EXCRETION IN NORMAL SUBJECTS AND IN CUSHING'S SYNDROME UTI- LIZING N-15 GLYCINE ORALLY AND INTRAVENOUSLY
}

\author{
By K. R. CRISPELL, WILLIAM PARSON, AND GARDNER HARDEN 1 wITH THE \\ TECHNICAL ASSISTANCE OF SARAH BRENT
}
(From the Department of Internal Medicine, University of Virginia School of Medicine, Charlottesville, Va.)

(Submitted for publication October 5, 1953; accepted .November 18, 1953)

In a previous paper (1) we have reported studies on the percentage of $\mathrm{N}-15$ excreted over a twenty-four hour period following the oral administration of $\mathrm{N}-15$ glycine to normal subjects and to patients with Cushing's syndrome in nitrogen equilibrium on diets containing approximately one gram of protein per kilogram of body weight. During this study it was noted that the level of protein intake influenced the percentage of $\mathrm{N}-15$ excreted in the urine, an observation first reported by Sprinson (2) in animals and in a healthy volunteer.

The present paper presents data on the influence of various levels of protein intake on the percentage of $\mathrm{N}-15$ excreted in the urine over a twenty-four hour period following either oral or intravenous administration of $\mathrm{N}-15$ glycine to healthy volunteers. Similar data from a patient with Cushing's syndrome given $\mathrm{N}-15$ glycine orally are also presented.

\section{MATERIALS AND METHODS}

The healthy volunteers (J. M., A. W., G. H., P. S., L. G., S. H., J. B., O. B.) were male medical students or house officers between the ages of 21 to 29 years. $\mathrm{Pa}$ tient M. C. was a 24-year old female with Cushing's syndrome shown by adrenal exploration to have adrenal hyperplasia.

The healthy volunteers were fed from the special diet kitchen of the metabolic unit. They carried out their usual laboratory duties while on the study. Patient M. C. was studied while on the metabolic unit.

The diets were arbitrarily defined as follows:

A normal protein diet contained approximately one gram of protein per kilogam of body weight.

A high protein diet contained at least 1.6 grams of protein per kilogram of body weight.

A low protein diet contained a maximum of $0.4 \mathrm{grams}$ of protein per kilogram of body weight.

The amount of nitrogen in the diets is recorded in Tables I and II. When a subject was studied on more

\footnotetext{
${ }^{1}$ Now at New York Hospital, New York, N. Y.
}

than one protein level, the diet was kept isocaloric except as recorded in Table I. An analysis of an aliquot of the diet was made at least once for each study. The nitrogen balance as recorded in Table III was estimated by an analysis of an aliquot of a 24-hour urine specimen by the macro-Kjehldahl technique. The fecal nitrogen was assumed to be 1.3 grams daily (3).

The method of the oral administration of $\mathrm{N}-15$ glycine was as previously described (1). The $\mathrm{N}-15$ glycine for intravenous administration was dissolved in $10 \mathrm{ml}$. of distilled water and then autoclaved. It was given intravenously over a five-minute period.

The subjects were given the $\mathrm{N}-15$ glycine with the breakfast meal or at breakfast time while in the fasting state (Tables I and II). The fasting state was an overnight fast and the breakfast meal was omitted with the other meals being given at the usual time followed at 9:00 p.m. with the breakfast meal so that the daily nitrogen and caloric intake remained constant. The amount of N-15 administered is recorded in Tables I and II. The subjects were given the $\mathrm{N}-15$ glycine after they had been on a diet for at least one week, and nitrogen equilibrium had been achieved except in a few instances as recorded in Table III.

The amount of $\mathrm{N}-15$ excreted in the urine over a 24-hour period was calculated by determining the $\mathrm{N}-15$ to $\mathrm{N}-14$ ratio of the urinary nitrogen by mass spectrometer analysis. The technique of preparing the samples for the mass spectrometer and the type of instrument was as previously described (1). Results are recorded in Tables I and II as the percentage of administered N-15 excreted in the urine in the first 24-hour period following the administration of the N-15 glycine.

\section{RESULTS}

\section{Normal diet}

The data on healthy subjects (A. W. and J. M.) were included in a previous paper (1) which reported that healthy young subjects in nitrogen equilibrium, both male and female, on a normal protein intake given $\mathrm{N}-15$ glycine orally with the breakfast meal excreted similar amounts of $\mathrm{N}-15$ over a 24-hour period (25.9 per cent S.D. \pm 1.6 ). 
TABLE I

Oral administration of $N^{15}$ glycine

\begin{tabular}{|c|c|c|c|c|c|c|c|}
\hline \multirow[b]{2}{*}{ Subject } & \multirow[b]{2}{*}{$\begin{array}{l}\text { Weight } \\
K_{\mathbf{g}} .\end{array}$} & & \multicolumn{2}{|c|}{ Nitrogen intake } & \multicolumn{3}{|c|}{ Urinary nitrogen } \\
\hline & & & $\begin{array}{l}\mathrm{N}^{14} \\
24 \mathrm{hrs} . \\
\mathrm{Gm} .\end{array}$ & $\begin{array}{c}\text { N1s } \\
\text { Single dose } \\
\text { mg. }\end{array}$ & $\begin{array}{c}\mathrm{Nu}^{\prime \prime} \\
24 \mathrm{hrs} . \\
\mathrm{Gm} .\end{array}$ & $\begin{array}{l}\mathrm{N}^{16} \\
24 \mathrm{hrs} . \\
\mathrm{mg} .\end{array}$ & $\begin{array}{c}\mathrm{N}^{\mathrm{Nis}} \\
24 \mathrm{hrs} \\
\%\end{array}$ \\
\hline \multicolumn{8}{|l|}{$\begin{array}{l}\text { Healthy volunteers } \\
\text { Normal diet }\end{array}$} \\
\hline $\begin{array}{l}\text { A. W. No. } 1 \\
\text { J. M. }\end{array}$ & $\begin{array}{l}97.0 \\
93.5 \\
80.0\end{array}$ & & $\begin{array}{l}16.1 \\
16.1 \\
12.1\end{array}$ & $\begin{array}{r}104 \\
104 \\
33\end{array}$ & $\begin{array}{l}14.8 \\
13.2 \\
11.4\end{array}$ & $\begin{array}{r}28.0 \\
29.3 \\
7.6\end{array}$ & $\begin{array}{l}27.0 \\
28.1 \\
23.0\end{array}$ \\
\hline $\begin{array}{l}\text { Normal diet } \\
\text { (Fasting) }\end{array}$ & & & & & & & \\
\hline $\begin{array}{l}\text { S. H. } \\
\text { High protein diet } \\
\text { (with breakfast) }\end{array}$ & 76.8 & & 12.1 & 20.8 & 10.8 & 5.4 & 25.9 \\
\hline $\begin{array}{l}\text { A. W. } \\
\text { Low protein diet }\end{array}$ & 91.6 & & 26.6 & 78 & 24.3 & 35.6 & 45.3 \\
\hline $\begin{array}{l}\text { (with breaktast) } \\
\text { J. M. } \\
\text { Cushing's syndrome }\end{array}$ & 80.0 & & 3.5 & 33 & 4.5 & 2.6 & 7.8 \\
\hline & & Calories & & & & & \\
\hline 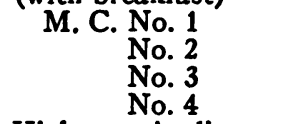 & $\begin{array}{l}62.9 \\
63.7 \\
61.5 \\
61.0\end{array}$ & $\begin{array}{r}1970 \\
1970 \\
1970 \\
860\end{array}$ & $\begin{array}{l}10.9 \\
10.9 \\
10.9 \\
11.0\end{array}$ & $\begin{array}{l}78 \\
39 \\
22 \\
39\end{array}$ & $\begin{array}{r}9.5 \\
10.1 \\
10.1 \\
10.2\end{array}$ & $\begin{array}{l}37.6 \\
20.2 \\
10.4 \\
17.8\end{array}$ & $\begin{array}{l}48.2 \\
51.7 \\
47.3 \\
45.2\end{array}$ \\
\hline $\begin{array}{l}\text { High protein diet } \\
\text { (with breakfast) }\end{array}$ & & & & & & & \\
\hline $\begin{array}{l}\text { M. C. No. } 1 \\
\text { No. } 2 \\
\text { Low protein diet }\end{array}$ & $\begin{array}{l}61.6 \\
59.8\end{array}$ & $\begin{array}{r}1970 \\
865\end{array}$ & $\begin{array}{l}18.0 \\
18.0\end{array}$ & $\begin{array}{l}33 \\
39\end{array}$ & $\begin{array}{l}14.7 \\
14.9\end{array}$ & $\begin{array}{l}14.7 \\
19.9\end{array}$ & $\begin{array}{l}44.5 \\
50.6\end{array}$ \\
\hline $\begin{array}{l}\text { M. C. } \\
\text { No. } 1 \\
\text { No. } 2\end{array}$ & $\begin{array}{l}62.2 \\
63.5\end{array}$ & $\begin{array}{r}2470 \\
860\end{array}$ & $\begin{array}{l}3.5 \\
3.5\end{array}$ & $\begin{array}{l}39 \\
39\end{array}$ & $\begin{array}{l}5.1 \\
4.5\end{array}$ & $\begin{array}{l}15.2 \\
10.7\end{array}$ & $\begin{array}{l}39.0 \\
27.4\end{array}$ \\
\hline
\end{tabular}

Subject S. H. given N-15 glycine orally while in the fasting state also excreted 26 per cent of the $\mathrm{N}-15$ in the urine in 24 hours.

Subjects (G. H., P. S., and L. G.) given N-15 glycine intravenously while fasting excreted an average of 17.2 per cent of the N-15 over a 24 hour period. Subject S. H. excreted 14.1 per cent of $\mathrm{N}-15$ over a 24 -hour period when given the $\mathrm{N}-15$ glycine intravenously while consuming the breakfast meal (Table II).

The data on patient M. C. were also included in a previous paper (1) where it was shown that three patients with Cushing's syndrome in nitrogen equilibrium given $\mathrm{N}-15$ glycine orally excreted an average of 47.9 per cent of the $\mathrm{N}-15$ over a 24 -hour period (Table I).

\section{High protein diet}

Subject A. W. given $\mathrm{N}-15$ glycine orally excreted 45.3 per cent of the $\mathrm{N}-15$ in 24 hours (Table I).
Subjects (O. B., P. S., and J. B.) given N-15 glycine intravenously while fasting excreted an an average of 32.6 per cent of the N-15 in 24 hours (Table II).

Patient M. C. given N-15 glycine orally on the high protein diet isocaloric with the normal protein diet excreted 45 per cent. When tested on a low caloric high protein diet she excreted 51 per cent (Table I).

\section{Low protein diet}

Subject J. M. given N-15 glycine orally excreted only 7.8 per cent of the $\mathrm{N}-15$ in 24 hours (Table I).

Subjects (O. B. and G. H.) given N-15 glycine intravenously while fasting excreted an average of 5 per cent of the $\mathrm{N}-15$ in 24 hours (Table II).

Patient M. C. on a low caloric diet excreted 27.4 per cent in 24 hours, and on a high caloric diet excreted 39.0 per cent in 24 hours with the N-15 glycine being administered orally on both occasions (Table I). 


\section{DISCUSSION}

It is clear that nitrogen equilibrium is quite readily achieved when protein consumption is varied widely. Classical nitrogen balance studies do not offer any explanation of the change in the "metabolic set" with respect to nitrogen metabolism. These studies utilizing N-15 offer some partial insight into the alteration in the handling of nitrogen.

The pertinent results are summarized in Tables I and II and show clearly that the $\mathrm{N}-15$ excretion in the urine after either oral or intravenous administration of $\mathrm{N}-15$ glycine is profoundly influenced by the previous level of protein intake in the diet. A high protein diet causes an increase and a low protein diet a decrease in the amount of $\mathrm{N}-15$ excreted over a twenty-four hour period as compared to a normal protein diet.

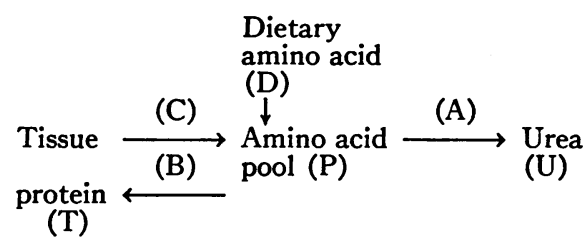

As shown in the above simplified version of the diagram used by Rittenberg (4), dietary amino acids (D) may be thought of as entering an amino acid pool (P). A portion is catabolized (A) to urea (U) and a portion is used to build tissue protein $(\mathrm{T})$. According to the present concept of the dynamic state there is a continuous synthesis (B) of tissue protein ( $\mathrm{T}$ ) associated with a continuous breakdown (C). Under conditions of nitrogen equilibrium, $B=C$. It is obvious that both the amino acids from the diet and from the breakdown of tissue protein contribute to the amino acid pool.

The most reasonable explanation for the large increase in the amount of $\mathrm{N}-15$ appearing in the urine on a high protein diet is an increase in the rate of reaction A. More specifically there is an increased rate of degradation of dietary glycine to urea. The increased excretion of N-15 is not due to an increased excretion of glycine per se because in both the normal and high protein diets approximately ninety per cent of the N-15 appears in the urea fraction. Also, Eckhardt and Davidson (5) have shown that a large fluctuation in the type and quantity of protein eaten results in only small changes in the quantity of amino acids excreted. The possibility that there is a significant increase in the rate of reaction $C$ can be ruled out since the $\mathrm{N}-15$ incorporated into tissue protein would be greatly diluted with normal nitrogen $(\mathrm{N}-14)$ and even a great increase in the degradative rate (C) would result in a very small amount of the $\mathrm{N}-15$ being excreted in twenty-four hours.

The decrease in the amount of $\mathrm{N}-15$ appearing in the urine on a low protein diet could be due either to a decrease in the rate of reaction $A$ or to

TABLE II

Intravenous administration of $N^{15}$ glycine

\begin{tabular}{|c|c|c|c|c|c|c|}
\hline \multirow[b]{2}{*}{ Subject } & \multirow[b]{2}{*}{$\begin{array}{c}\text { Weight } \\
\text { Kg. }\end{array}$} & \multicolumn{2}{|c|}{ Nitrogen intake } & \multicolumn{3}{|c|}{ Urinary nitrogen } \\
\hline & & $\begin{array}{l}\mathrm{Nl4} \\
24 \mathrm{hrs} \\
\mathrm{Gm} .\end{array}$ & $\begin{array}{c}\text { N1s } \\
\text { Single dose } \\
m g .\end{array}$ & $\begin{array}{l}\text { Nis. } \\
24 \mathrm{hrs} . \\
\mathrm{Gm} .\end{array}$ & $\begin{array}{c}\mathrm{N} / \mathrm{s} \\
24 \mathrm{hrs} . \\
\mathrm{mg} .\end{array}$ & $\begin{array}{c}\mathrm{N}^{16} \\
24 \mathrm{hrs}\end{array}$ \\
\hline \multicolumn{7}{|l|}{$\begin{array}{l}\text { Healthy volunteers } \\
\text { Normal diet } \\
\text { (Fasting) }\end{array}$} \\
\hline $\begin{array}{l}\text { G. H. } \\
\text { P.S. } \\
\text { L. G. }\end{array}$ & $\begin{array}{l}77.7 \\
71.8 \\
77.8\end{array}$ & $\begin{array}{l}12.3 \\
11.8 \\
12.7\end{array}$ & $\begin{array}{l}30 \\
30 \\
60\end{array}$ & $\begin{array}{r}10.9 \\
9.5 \\
11.3\end{array}$ & $\begin{array}{r}5.35 \\
4.85 \\
10.56\end{array}$ & $\begin{array}{l}17.8 \\
16.2 \\
17.6\end{array}$ \\
\hline $\begin{array}{l}\text { Normal diet } \\
\text { (with breakfast) }\end{array}$ & & & & & & \\
\hline $\begin{array}{l}\text { S. H. } \\
\text { High protein diet }\end{array}$ & 75.3 & 12.0 & 30 & 10.6 & 4.24 & 14.1 \\
\hline $\begin{array}{l}\text { (Fasting) } \\
\text { J. B. } \\
\text { O. B. } \\
\text { P. S. }\end{array}$ & $\begin{array}{l}70.0 \\
71.6 \\
71.6\end{array}$ & $\begin{array}{l}27.9 \\
28.6 \\
23.0\end{array}$ & $\begin{array}{l}24 \\
30 \\
30\end{array}$ & $\begin{array}{l}27.7 \\
26.0 \\
22.2\end{array}$ & $\begin{array}{l}8.60 \\
9.75 \\
8.88\end{array}$ & $\begin{array}{l}35.8 \\
32.5 \\
29.6\end{array}$ \\
\hline $\begin{array}{l}\text { Low protein diet } \\
\text { (Fasting) }\end{array}$ & & & & & & \\
\hline O. B. & $\begin{array}{l}72.0 \\
77.6\end{array}$ & $\begin{array}{l}4.1 \\
4.2\end{array}$ & $\begin{array}{l}30 \\
30\end{array}$ & $\begin{array}{l}3.5 \\
2.9\end{array}$ & $\begin{array}{l}1.54 \\
1.45\end{array}$ & $\begin{array}{l}5.1 \\
4.8\end{array}$ \\
\hline
\end{tabular}


TABLE III

Oral administration of $N^{16}$ glycine

\begin{tabular}{|c|c|c|c|c|c|c|c|c|c|c|c|}
\hline \multirow[b]{3}{*}{ Subject } & \multirow{3}{*}{$\begin{array}{l}\text { Wt. range } \\
K_{g} .\end{array}$} & \multicolumn{10}{|c|}{ Daily nitrogen balance } \\
\hline & & \multicolumn{5}{|c|}{ Days before tag } & \multicolumn{5}{|c|}{ Days after tag } \\
\hline & & 5 & 4 & 3 & 2 & 1 & 1 & 2 & 3 & 4 & 5 \\
\hline $\begin{array}{l}\text { Healthy volunteers } \\
\text { Normal protein diet } \\
\text { A. W. No. } 1 \\
\text { J. M. No. } 2 \\
\text { S. H. }\end{array}$ & $\begin{array}{l}95.4-97.7 \\
91.8-93.6 \\
80.0-80.1 \\
76.8-76.9\end{array}$ & $\begin{array}{l}-1.2 \\
-0.2 \\
-3.8 \\
-1.2\end{array}$ & $\begin{array}{l}-1.4 \\
-0.1 \\
-3.3 \\
-0.4\end{array}$ & $\begin{array}{l}-0.2 \\
-0.2 \\
-2.1 \\
-0.2\end{array}$ & $\begin{array}{l}-0.3 \\
-0.1 \\
-1.2 \\
+0.1\end{array}$ & $\begin{array}{r}-1.0 \\
-0.1 \\
-0.3 \\
0.0\end{array}$ & $\begin{array}{l}-0.2 \\
-0.1 \\
-0.6 \\
0.0\end{array}$ & $\begin{array}{l}+0.2 \\
-0.7 \\
-0.3\end{array}$ & $\begin{array}{l}+0.4 \\
-0.5 \\
+0.4\end{array}$ & $\begin{array}{l}+\underline{0.7} \\
+\underline{+0.1}\end{array}$ & $\underline{-1}$ \\
\hline $\begin{array}{l}\text { High protein diet } \\
\text { A. W. }\end{array}$ & $91.9-90.0$ & - & - & +3.7 & +2.2 & +1.2 & +0.8 & +0.4 & -0.2 & - & - \\
\hline $\begin{array}{l}\text { Jushing's syndrome } \\
\text { Normal protein diet }\end{array}$ & $80.0-80.4$ & -2.5 & -2.8 & -3.7 & -1.6 & -1.2 & -2.3 & -2.3 & -2.4 & - & - \\
\hline $\begin{array}{l}\text { M. C. No. } 1 \\
1970 \text { cal. No. } 2 \\
\text { No. } 3 \\
860 \text { cal. No. } 4 \\
\end{array}$ & $\begin{array}{l}62.8-63.6 \\
63.5-63.8 \\
61.3-61.6 \\
61.3-61.0\end{array}$ & $\begin{array}{r}\overline{-} \\
-0.1 \\
0.0 \\
+0.7\end{array}$ & $\begin{array}{l}+0.5 \\
-0.2 \\
+0.2 \\
+0.7\end{array}$ & $\begin{array}{l}-0.1 \\
-0.4 \\
-0.4 \\
-0.6\end{array}$ & $\begin{array}{l}-0.4 \\
-0.4 \\
-0.5 \\
-\end{array}$ & $\begin{array}{l}+1.4 \\
-0.3 \\
-0.4 \\
+0.6\end{array}$ & $\begin{array}{l}+0.1 \\
-0.5 \\
-0.5 \\
-0.5\end{array}$ & $\begin{array}{l}+0.4 \\
-0.7 \\
-0.4 \\
+0.3\end{array}$ & $\begin{array}{r}+0.3 \\
+0.6 \\
0.0 \\
-0.1\end{array}$ & $\begin{array}{l}+0.3 \\
+0.2 \\
-0.2 \\
+1.3\end{array}$ & $\begin{array}{l}+0.6 \\
-0.7 \\
-0.2\end{array}$ \\
\hline $\begin{array}{l}865 \text { cal. No. } 5 \\
1970 \mathrm{cal} \text {. No. } 6\end{array}$ & $\begin{array}{l}60.1-60.4 \\
60.0-59.7\end{array}$ & $\overline{+1.6}$ & $\begin{array}{l}+3.3 \\
+1.3\end{array}$ & $\begin{array}{l}+1.0 \\
+1.1\end{array}$ & $\begin{array}{l}+1.2 \\
+2.4\end{array}$ & $\begin{array}{l}+1.7 \\
+0.6\end{array}$ & $\begin{array}{l}+1.8 \\
+1.8\end{array}$ & $\begin{array}{l}+0.4 \\
+1.5\end{array}$ & $\begin{array}{l}-0.5 \\
+2.4\end{array}$ & $\begin{array}{l}-0.1 \\
+0.9\end{array}$ & $\stackrel{+0.5}{-}$ \\
\hline $\begin{array}{l}860 \text { cal. No. } 7 \\
2470 \text { cal. No. } 8\end{array}$ & $\begin{array}{l}62.2-61.6 \\
63.6-63.8\end{array}$ & $\begin{array}{l}-1.7 \\
-1.1\end{array}$ & $\begin{array}{l}-2.4 \\
-1.1\end{array}$ & $\begin{array}{l}-2.8 \\
-1.1\end{array}$ & $\begin{array}{l}-2.4 \\
-1.3\end{array}$ & $\begin{array}{l}-2.0 \\
-1.0\end{array}$ & $\begin{array}{l}-2.3 \\
-1.1\end{array}$ & $\begin{array}{l}-2.0 \\
-1.1\end{array}$ & $\begin{array}{l}-1.6 \\
-1.6\end{array}$ & $\begin{array}{l}-1.2 \\
-1.2\end{array}$ & $\begin{array}{l}-1.3 \\
-1.3\end{array}$ \\
\hline \multicolumn{12}{|c|}{ Intravenous administration of $N^{15}$ glycine } \\
\hline $\begin{array}{l}\text { Normal protein diet } \\
\text { P.S. } \\
\text { G. H. } \\
\text { L. G. } \\
\text { S. H. }\end{array}$ & $\begin{array}{l}70.7-71.6 \\
77.7-78.1 \\
77.7-77.9 \\
74.5-76.0\end{array}$ & $\begin{array}{l}-0.9 \\
+1.6 \\
-1.2 \\
-0.1\end{array}$ & $\begin{array}{l}-0.2 \\
+2.2 \\
-0.4 \\
+0.1\end{array}$ & $\begin{array}{l}-0.9 \\
+0.9 \\
-0.5 \\
-0.1\end{array}$ & $\begin{array}{l}+0.3 \\
+0.1 \\
-0.2 \\
-0.3\end{array}$ & $\begin{array}{l}+0.4 \\
+0.4 \\
+0.1 \\
-0.3\end{array}$ & $\begin{array}{l}+1.0 \\
+0.1 \\
-0.6 \\
+0.2\end{array}$ & $\begin{array}{l}\overline{\bar{z}} \\
\overline{-0.4} \\
+0.6\end{array}$ & $\overline{\bar{z}}$ & $\overline{\bar{z}}$ & $\overline{\bar{z}}$ \\
\hline $\begin{array}{l}\text { High protein diet } \\
\text { O. B. } \\
\text { P.S. } \\
\text { J. B. }\end{array}$ & $\begin{array}{l}71.6-71.8 \\
71.6-71.9 \\
70.0-70.1\end{array}$ & $\begin{array}{l}+1.1 \\
+2.8 \\
+0.7\end{array}$ & $\begin{array}{l}+2.5 \\
+1.3 \\
-1.1\end{array}$ & $\begin{array}{l}+0.9 \\
+0.6 \\
-0.2\end{array}$ & $\begin{array}{l}+2.2 \\
+1.1 \\
0.0\end{array}$ & $\begin{array}{l}+1.3 \\
+1.4 \\
-0.5\end{array}$ & $\begin{array}{l}+0.3 \\
-0.6 \\
-1.1\end{array}$ & $\stackrel{+2.1}{=}$ & $\begin{array}{l}+2.2 \\
+1.5 \\
-0.8\end{array}$ & $\overline{\overline{+0.4}}$ & $\bar{z}$ \\
\hline $\begin{array}{l}\text { Low protein diet } \\
\text { G. H. } \\
\text { O. B. }\end{array}$ & $\begin{array}{l}77.6-78.2 \\
71.9-72.0\end{array}$ & $\begin{array}{l}-1.7 \\
-2.5\end{array}$ & $\begin{array}{l}-1.4 \\
-1.9\end{array}$ & $\begin{array}{l}-1.3 \\
-0.7\end{array}$ & $\begin{array}{l}-0.7 \\
-1.4\end{array}$ & $\begin{array}{l}-1.3 \\
-0.4\end{array}$ & $\begin{array}{r}0.0 \\
-0.7\end{array}$ & $\begin{array}{l}+0.7 \\
-1.8\end{array}$ & $\begin{array}{l}-1.4 \\
-0.4\end{array}$ & $\begin{array}{l}-0.1 \\
-0.7\end{array}$ & -0.6 \\
\hline
\end{tabular}

an increase in the rate of reaction $\mathrm{B}$. The data do not permit differentiation between these two possibilities.

Of interest also is the fact that there was a decreased percentage of $\mathrm{N}-15$ excreted following intravenous as compared with oral administration.

In animal experiments with amino acid mixtures several investigators have demonstrated that tissue anabolism occurs only when all the essential amino acids are supplied simultaneously $(6,7)$. A time interval any greater than one hour between the ingestion of an incomplete amino acid mixture and its supplementation with the missing amino acids resulted in the failure of tissue synthesis (6). In this study with a non-essential amino acid no difference in $\mathrm{N}-15$ excretion was observed when a comparison was made of the ex- periments when the $\mathrm{N}-15$ glycine was given concurrently with breakfast with those where the food was not ingested until four hours after the $\mathrm{N}-15$ glycine was given.

Utilization of the technique of San Pietro and Rittenberg (8), which permits a mathematical calculation of the data and derivation of synthesis rates, is underway using both tagged essential and non-essential amino acids and may offer further information regarding utilization of amino acids.

We have previously reported (1) that patients with Cushing's syndrome in nitrogen equilibrium excrete approximately 48 per cent of the $\mathrm{N}-15$ in 24 hours as compared to about 26 per cent in normal subjects. The data suggested that this represented decreased protein synthesis and increased 
degradation and excretion of ingested amino acids. Clark (9) has recently reported observations in animals which are in accord with this concept of the action of cortisone on protein metabolism.

Patient M. C., with Cushing's syndrome on a high protein diet did not excrete a significantly increased amount of $\mathrm{N}-15$ ( 50.5 per cent) as compared to the normal diet ( 47.9 per cent). This suggests that in Cushing's syndrome the degradation of ingested amino acids was at a "maximum" and was not further increased by increasing the dietary protein.

\section{SUMMARY AND CONCLUSIONS}

1. The percentage of $\mathrm{N}-15$ excreted in the urine over a 24-hour period following either the oral administration or intravenous injection of $\mathrm{N}-15$ glycine has been determined in healthy subjects on various levels of protein intake in approximate nitrogen equilibrium.

2. An increased level of protein intake caused an increased excretion of $\mathrm{N}-15$ in the urine and a decreased protein intake caused a decreased excretion of $\mathrm{N}-15$ in the urine. The pattern of excretion was the same whether the N-15 glycine was given orally or intravenously, although the percentage excreted was lower after the intravenous route.

3. The excretion of $\mathrm{N}-15$ was not influenced by the food being ingested concurrently with glycine $\mathrm{N}-15$ administration or ingested four hours later.

4. When a patient with Cushing's syndrome was put on a high protein diet the urinary excretion of N-15 was not increased from what it had been on a normal protein intake.

\section{REFERENCES}

1. Parson, W., Crispell, K. R., and Ebbert, A., Jr., Abnormalities in $\mathrm{N}^{15}$ excretion rates after ingestion of tagged glycine in Cushing's syndrome and following ACTH administration. J. Clin. Invest., 1952, 31, 548.

2. Sprinson, D. S., Tracer studies on the metabolism of proteins in A Symposium on the Use of Isotopes in Biology and Medicine, Madison, Univ. of Wisconsin Press, 1948, p. 182.

3. Reifenstein, E. C., Jr., Albright, F., and Wells, S. L., The accumulation, interpretation, and presentation of data pertaining to metabolic balances, notably those of calcium, phosphorus, and nitrogen. J. Clin. Endocrinol., 1945, 5, 367.

4. Rittenberg, D., Dynamic aspects of the metabolism of amino acids. The Harvey Lectures, 1948-1949, 44, 200.

5. Eckhardt, R. D., and Davidson, C. S., Urinary excretion of amino acids by a normal adult receiving diets of varied protein content. J. Biol. Chem., 1949, 177, 687.

6. Cannon, P. R., Steffee, C. H., Frazier, L. J., Rowley, D. A., and Stepto, R. C., The influence of time of ingestion of essential amino acids upon utilization in tissue-synthesis. Federation Proc., 1947, 6, 390.

7. Geiger, E., Experiments with delayed supplementation of incomplete amino acid mixtures. J. Nutrition, 1947, 34, 97.

8. San Pietro, A., and Rittenberg, D., A study of the rate of protein synthesis in humans. II. Measurement of the metabolic pool and the rate of protein synthesis. J. Biol. Chem., 1953, 201, 457.

9. Clark, I., The effect of cortisone upon protein synthesis. J. Biol. Chem., 1953, 200, 69. 